\title{
Analysing County and Local Public Passenger Transport in the City of Velika Gorica
}

DOI: https://doi.org/10.7307/ptsm.2020.5

\author{
Luka Vidan $^{1}$, Marko Slavulj ${ }^{2}$ Dino Šojat ${ }^{2}$ \\ Faculty of Transport and Traffic Sciences, Student ${ }^{1}$; Faculty of Transport and Traffic Sciences
}

\section{Keywords:}

bus

City of Velika Gorica

public transport

timetable

transport demand

\begin{abstract}
This paper presents an analysis of the existing local public transport in the City of Velika Gorica and a few solutions to optimize the existing local public transport. In this paper, the management of passenger transport was analysed from a theoretical point of view, with data on transport demand between Zagreb and Velika Gorica being used. Transport demand analysis is shown by graphs, tables, and route data. In the proposed solution, smaller buses on some routes were introduced, timetables were changed, and Route 330 was cancelled.
\end{abstract}

\section{Introduction}

Citizen mobility of today is a significant factor in quality of life. Therefore, traffic planning faces the task of successfully solving mobility challenges, to ensure maximum savings for the users. Today's connection between Zagreb and Velika Gorica relies mostly on private cars and bus public transport. The aim of this paper is to conduct an analysis of the current situation, and to assess the existing transport service.

The chapter "General data" describes the conditions in the City of Velika Gorica. The data about population of the 58 settlements in the gravitational area of Velika Gorica and daily migrations between Velika Gorica and Zagreb is presented.

In chapter "Analysis of existing organization and infrastructure of public transport", an analysis of local public transport and inter-county transport between Zagreb and Velika Gorica is presented. A survey on 180 passengers was conducted to show the results graphically.

The chapter "Transport demand" shows travel time distributions between Zagreb and Velika Gorica, bus occupancy, and characteristics of vehicle fleet operating in Velika Gorica.

The last chapter, "Quality assessment of the existing transport service", provides an evaluation of the data analysed in the paper. Based on the evaluation, hypothetical solution scenarios were proposed. 


\section{Analysis of the current public transport service}

The area of the City of Velika Gorica is $330 \mathrm{~km}^{2}$ and it contains 58 settlements of which Velika Gorica is the only one that is considered an urban settlement. By 2011 census, the City of Velika Gorica had 31,553 residents, with 63,517 residents in the urban area, which makes it the sixth most populous city in Croatia. Figure 1 shows the population from 1900 to the 2001, and currently, there are 63,517 residents in urban area. The census from 2011. resulted in the same population compared to 2001. [1]

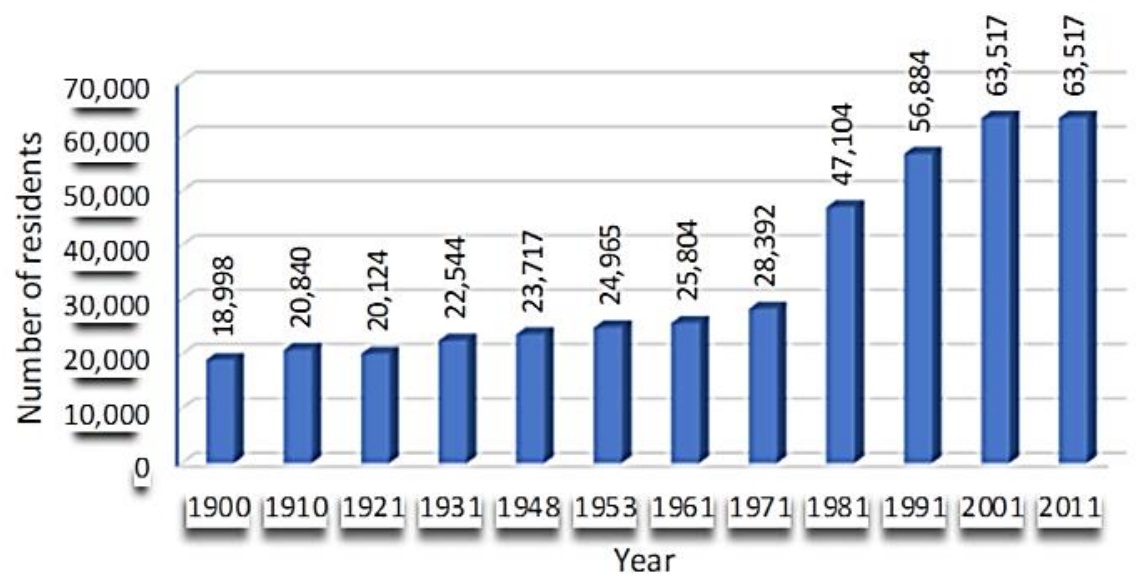

Figure 1. The number of residents in Velika Gorica

Source: [1]

Figure 2 shows all 58 settlements and population in every settlement.

\begin{tabular}{|l|r|}
\hline \multicolumn{1}{|c|}{ Settlment } & Population \\
\hline Bapća & 129 \\
\hline Bukovčak & 65 \\
\hline Buševec & 886 \\
\hline Cerovski Vrh & 93 \\
\hline Cvetković Brdo & 32 \\
\hline Črnkovec & 412 \\
\hline Donja Lomnica & 1,732 \\
\hline Donje Podotočje & 375 \\
\hline Drenje Ščitarjevsko & 203 \\
\hline Dubranec & 349 \\
\hline Gornja Lomnica & 580 \\
\hline Gornje Podotočje & 491 \\
\hline Gradići & 1,860 \\
\hline Gudci & 374 \\
\hline Gustelnica & 118 \\
\hline Jagodno & 521 \\
\hline Jerebić & 41 \\
\hline Ključić Brdo & 214 \\
\hline Kobilić & 533 \\
\hline Kozjača & 342 \\
\hline
\end{tabular}

\begin{tabular}{|l|r|}
\hline \multicolumn{1}{|c|}{ Settlment } & Population \\
\hline Kuče & 1,453 \\
\hline Lazi Turopoljski & 57 \\
\hline Lazina Čička & 566 \\
\hline Lekneno & 383 \\
\hline Lukavec & 1,140 \\
\hline Mala Buna & 261 \\
\hline Mala Kosnica & 49 \\
\hline Markuševec Turopoljski & 328 \\
\hline Mičevec & 1,286 \\
\hline Mraclin & 1,074 \\
\hline Novaki Ščitarjevski & 158 \\
\hline Novo Čiče & 1,255 \\
\hline Obrezina & 555 \\
\hline Ogulinec & 292 \\
\hline Okuje & 467 \\
\hline Petina & 213 \\
\hline Petravec & 76 \\
\hline Petrovina Turopoljska & 708 \\
\hline Poljana Čička & 688 \\
\hline Prvonožina & 42 \\
\hline
\end{tabular}

\begin{tabular}{|l|r|}
\hline \multicolumn{1}{|c|}{ Settlment } & Population \\
\hline Rakitovec & 570 \\
\hline Ribnica & 803 \\
\hline Sasl & 159 \\
\hline Selnica Ščitarjevska & 535 \\
\hline Sop Bukevski & 85 \\
\hline Staro Čiče & 790 \\
\hline Strmec Bukevski & 366 \\
\hline Ščitarjevo & 442 \\
\hline Šiljakovina & 672 \\
\hline Trnje & 62 \\
\hline Turopolje & 953 \\
\hline Velika Buna & 856 \\
\hline Velika Gorica & 31,553 \\
\hline Velika Kosnica & 770 \\
\hline Velika Mlaka & 3,334 \\
\hline Vukomerić & 158 \\
\hline Vukovina & 947 \\
\hline Zablatje Posavsko & 61 \\
\hline
\end{tabular}

Figure 2. Settlement population in the administrative area of Velika Gorica

Source: [2]

Velika Gorica is a city in Zagreb County, bordering Zagreb County and the City of Zagreb. Due to its position in the gravitational area of Zagreb, about 50 to $60 \%$ of residents travel to Zagreb daily, which is shown in Figure 3. 


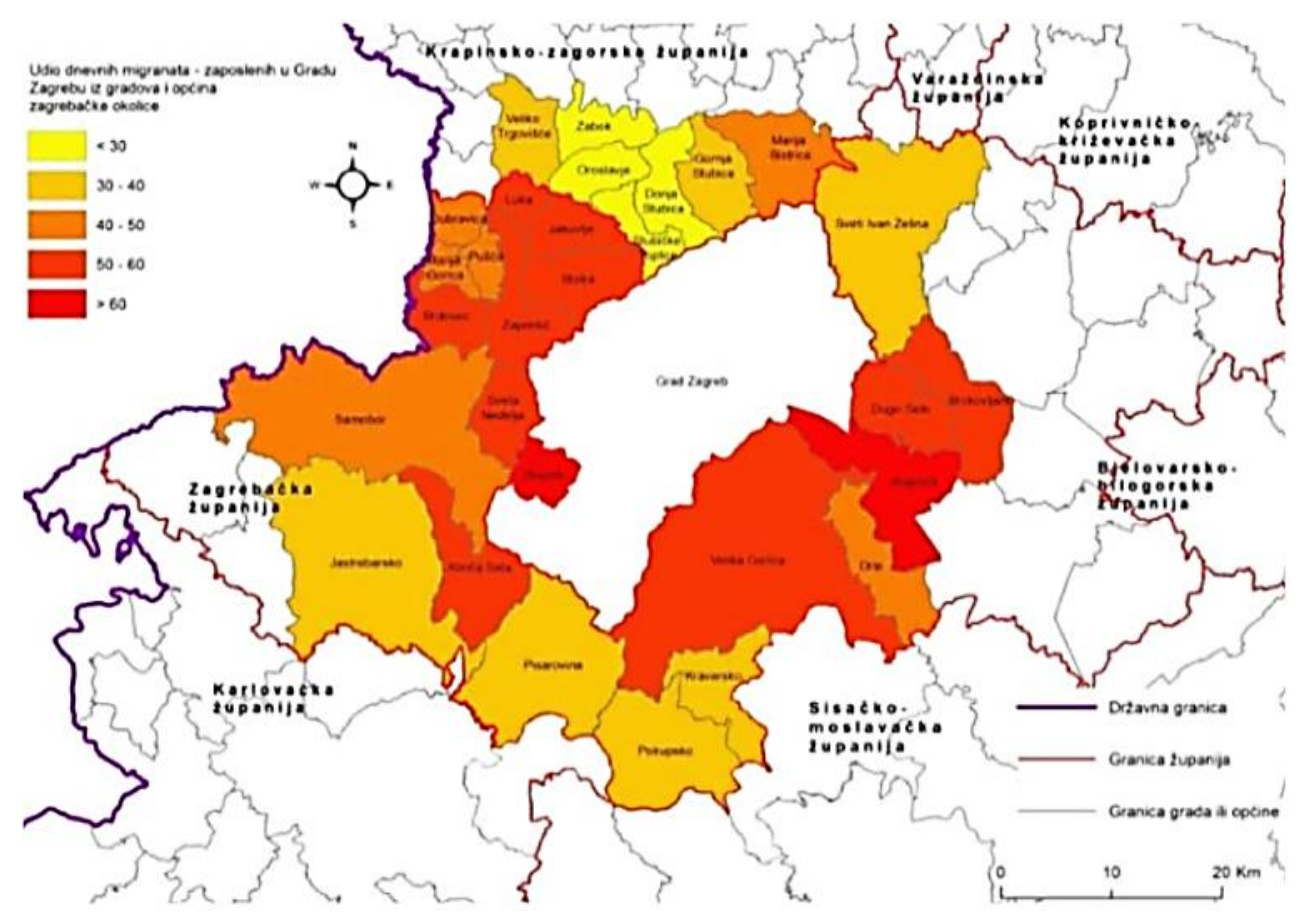

Figure 3. Daily citizen migrations from Velika Gorica

Source: [3]

\section{Local public transport}

Local public transport is currently organized to connect surrounding settlements and the administrative territory of the City of Velika Gorica. In total, there is $196 \mathrm{~km}$ of local public transport routes in the city, achieving $953,000.00 \mathrm{~km}$ yearly.

There are 13 local transport routes connecting surrounding settlements with the administrative territory, [5]:

1. Route $302 \rightarrow$ from Velika Gorica to Velika Buna. Some rides go off route to Ključić Brdo and then to Velika Buna

2. Route $303 \rightarrow$ from Velika Gorica to Kozjača. Sometimes, depending on the schedule, on its way back to Velika Gorica, the buses pass through Velika Buna with a few more stops on the route

3. Route $304 \rightarrow$ from Velika Gorica to Mraclin, with some rides extending to Vukojevac

4. Route $305 \rightarrow$ from Velika Gorica to Turopolje

5. Route $309 \rightarrow$ from Velika Gorica to Sasi

6. Route $310 \rightarrow$ two types:

$>$ from Glavni Kolodvor to Petrovina Turopoljska;

$>$ from Velika Gorica to Glavni Kolodvor passing through Petrovina Turopoljska

7. Route $319 \rightarrow$ from Velika Gorica to Lukavec

8. Route $321 \rightarrow$ from Velika Gorica to Strmec Bukevski, sometimes off route to Sasi and back on route to Strmec Bukevski

9. Route $323 \rightarrow$ from Velika Gorica through Ribnica and Lazina, making a small loop and returning to Velika Gorica

10. Route $324 \rightarrow$ from Velika Gorica to Čička Poljana

11. Route $325 \rightarrow$ from Velika Gorica to Vukojevac and sometimes, depending on its schedule, stops at Mraclin

12. Route $326 \rightarrow$ from Velika Gorica to ZTC (Zrakoplovno Tehnički Centar)

13. Route $335 \rightarrow$ from Velika Gorica to Pleso, extending to Donja Lomnica and returning to Velika Gorica. 


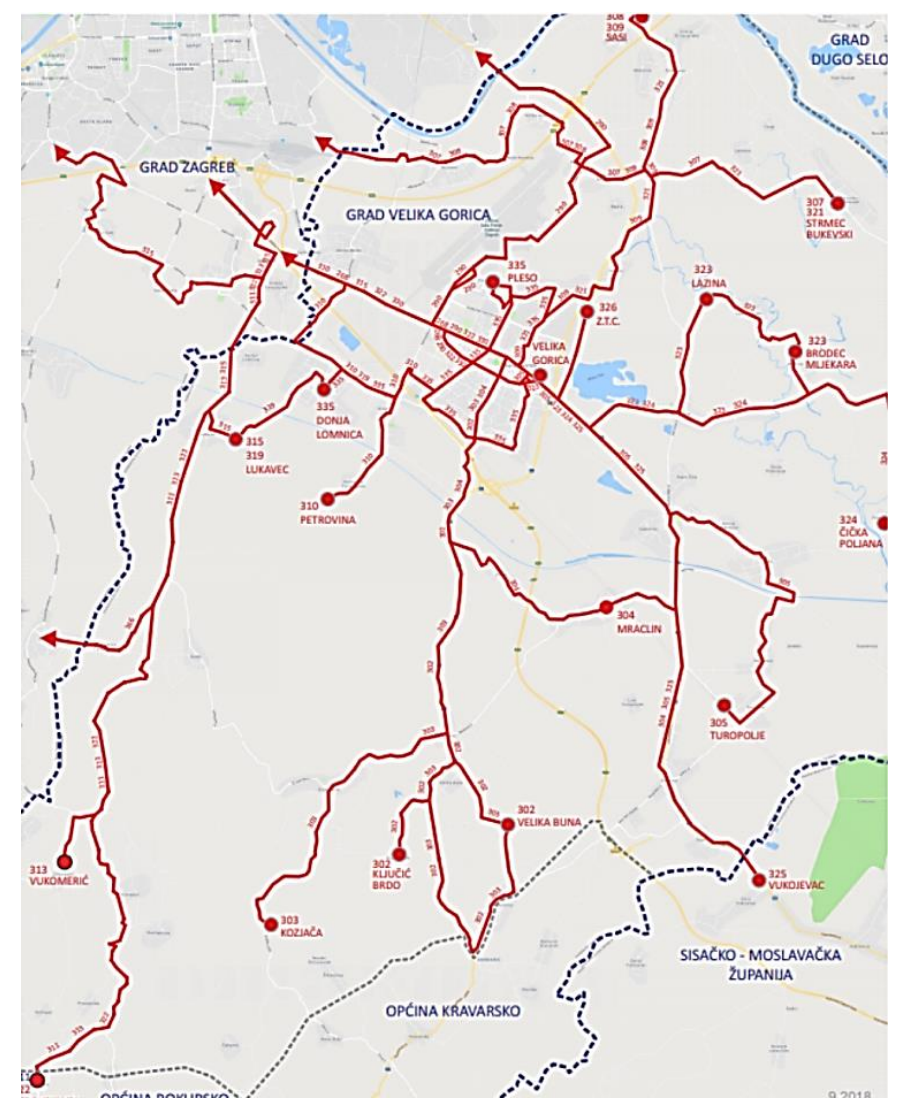

Figure 4. Local public transport routes

Source: [3]

Figure 4 shows local public transport routes in the City of Velika Gorica and the connections with the city. The routes connecting rural areas mostly are not economically effective because of less passengers, but the routes operate subsidized to create acceptable conditions for residents travelling from those parts of region. [3]

\section{Inter-county public transport}

Because Velika Gorica is close to the capital and the largest city of the Republic of Croatia, daily migrations between the cities are high. As already shown in Chapter 2, 50 to $60 \%$ of residents migrate to Zagreb and among the people, not only commuters (most of them own a private car) travel, but also children to school and students to universities in Zagreb. Local public transport needs to perfectly function mostly because of schoolchildren and students. The routes that operate in between the counties are 268, 290 and 330. These three routes transport most passengers between the cities.

In the purpose of exploring traffic demand and questioning quality of transportation service, a survey on 180 subjects on these three routes was conducted. Survey on route 330, was conducted on Monday $15^{\text {th }}$ of May 2017. For route 268, survey was conducted on Tuesday $16^{\text {th }}$ of May 2017, and the last route 290 was conducted on Monday $22^{\text {nd }}$ of May 2017.

The passengers were asked about their social status, and $60 \%$ of them declared as students and $30 \%$ as employed, shown in Figure 5. [1] 
Vidan, L., Slavulj, M., Šojat, D. / Public Transport \& Smart Mobility 2020, 39-49

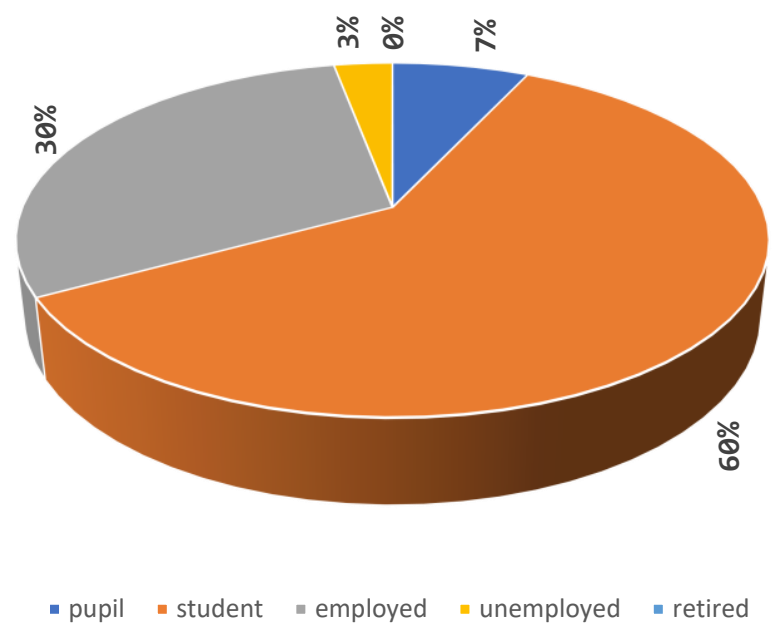

Figure 5. Social status of subjects

Source: [1]

When asked about the purpose of traveling by bus, $29.1 \%$ of them stated that the most common purpose is education (school or university), and 23.9\% opted to work, as shown in Figure 6. [1]

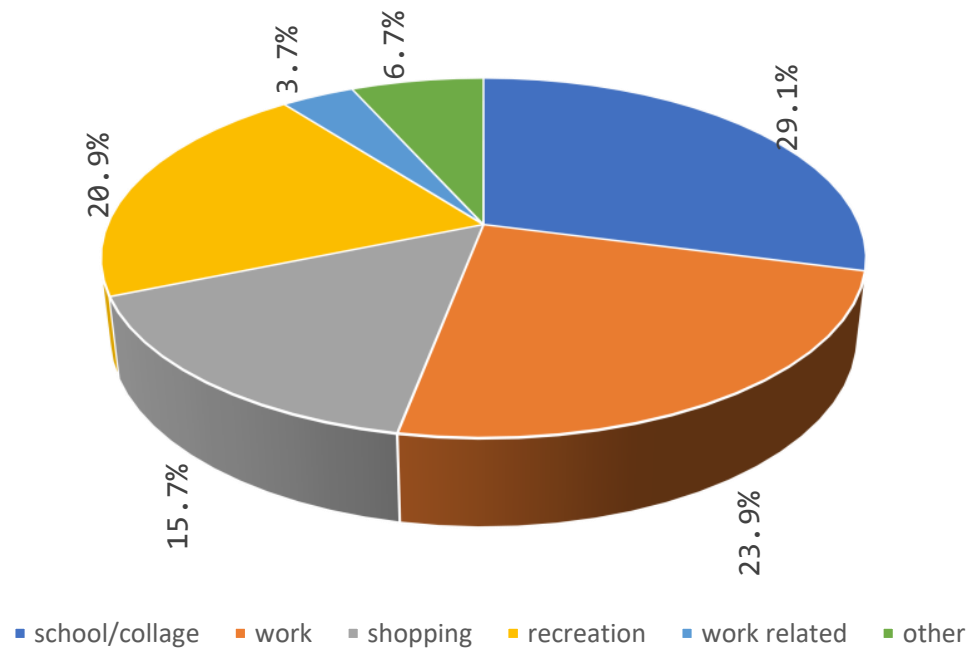

Figure 6. Travel purpose

Source: [1]

Figure 7 shows that $68.3 \%$ of subjects travel by route $268,21.7 \%$ by route 330 and $10 \%$ by route 290. [3] 


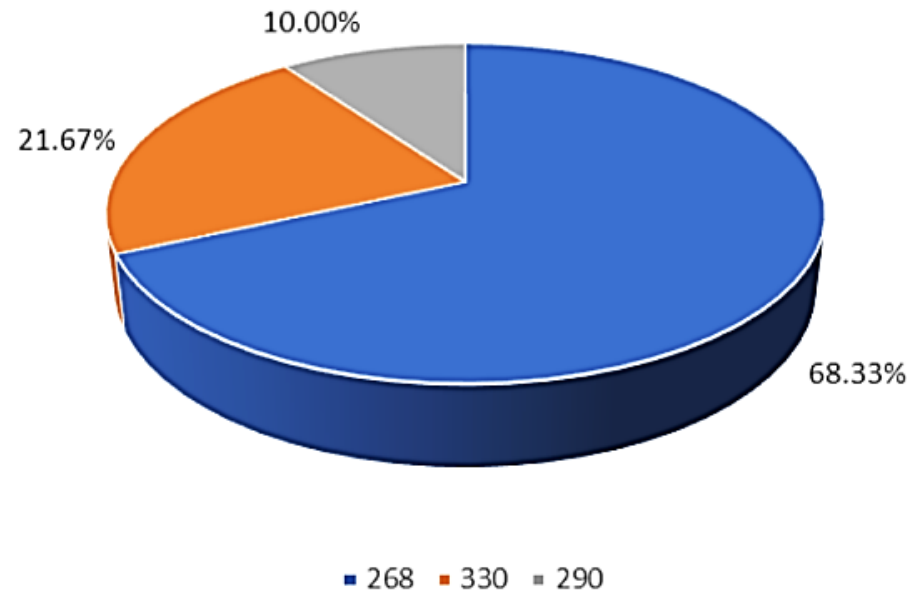

Figure 7. Routes the subjects are using daily

Source: [1]

Figure 8 shows passenger satisfaction with the service for different quality categories - safety, speed, comfort, accuracy and punctuality of transport.

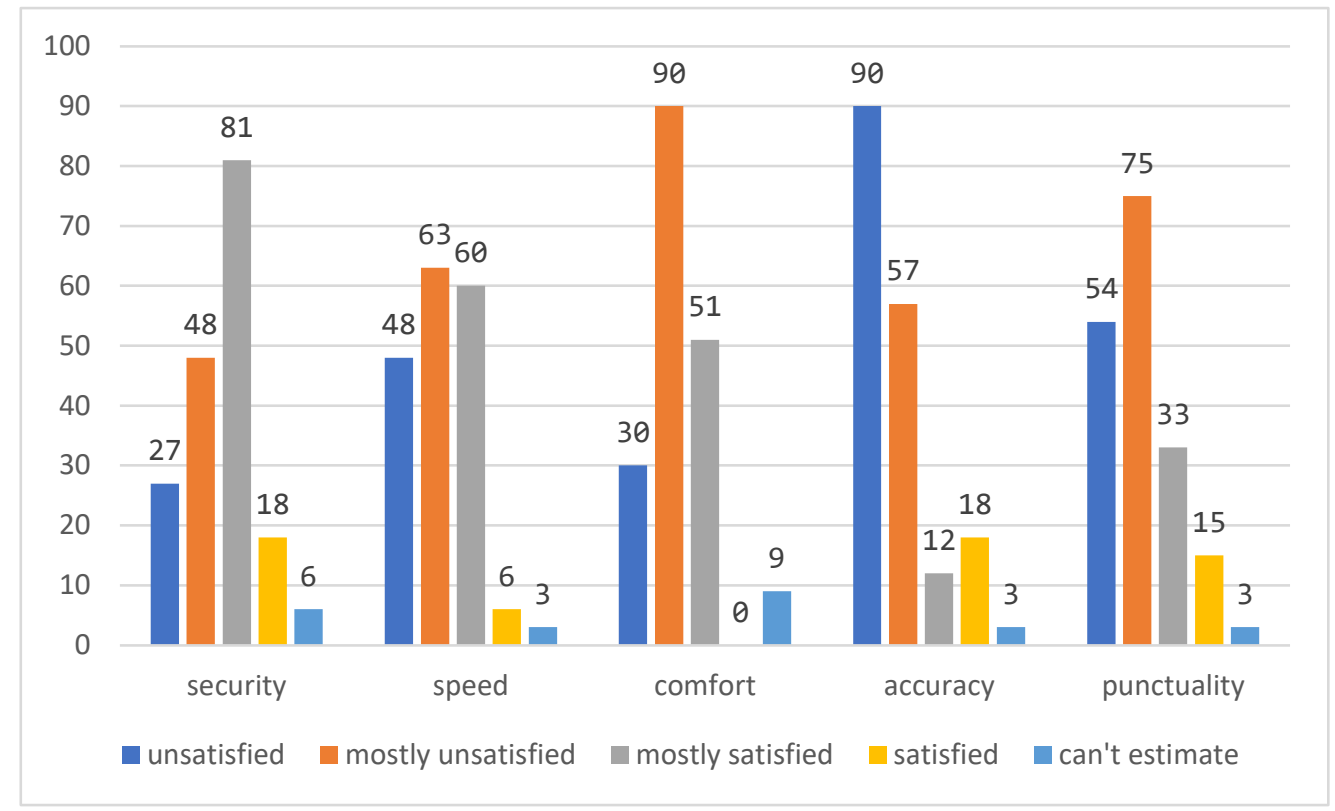

Figure 8. Quality of service and passenger satisfaction

Source: [1]

\section{Transport demand}

Transport demand always changes, and it depends on number of factors. The highest transport demand is in commuter periods (6:00 a.m. - 9:00 a.m.) and it's the easiest to predict. But there are other factors influencing demand more difficult to predict such as: weather, social activities, personal errands and day of week, because people tend to get from work earlier on Friday. That's why it's important to conduct surveys and monitor the passenger movements so that demand does not exceed the supply. 
Vidan, L., Slavulj, M., Šojat, D. / Public Transport \& Smart Mobility 2020, 39-49

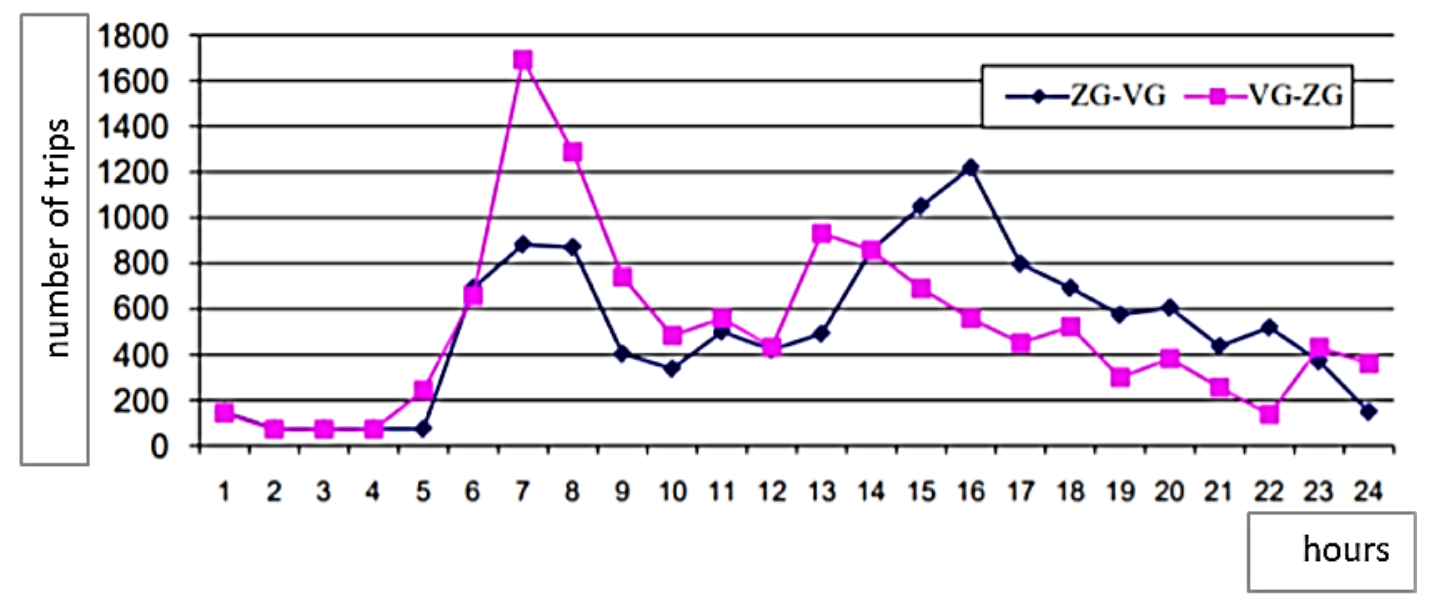

Figure 9. Daily travel distribution between Zagreb and Velika Gorica

Source: [3]

Figure 9, showing daily travel distribution in one-hour segments, reveals the unbalanced travel demand. This unbalanced demand affects vehicle occupancy. [3]

Based on the conducted analysis of public transport routes operating in Velika Gorica (Table 1), there are significant variations in driving speed, mainly depending on traffic conditions. [3]

Table 1. Features of travelling on public transport routes

\begin{tabular}{|c|c|c|c|}
\hline \multicolumn{2}{|c|}{ Route } & \multirow{2}{*}{ Travel duration (min) } & \multirow{2}{*}{ Average speed $(\mathrm{km} / \mathrm{h})$} \\
\hline Type & Number & & \\
\hline \multirow{10}{*}{ 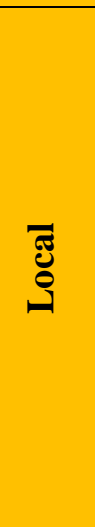 } & 303 & 29 & 32,90 \\
\hline & 304 & 28 & 38,36 \\
\hline & 305 & 20 & 35,70 \\
\hline & 309 & 20,5 & 33,37 \\
\hline & 319 & 18 & 31,00 \\
\hline & 321 & 19 & 37,58 \\
\hline & 323 & 32 & 30,75 \\
\hline & 324 & 18 & 43,50 \\
\hline & 335 & 26 & 23,08 \\
\hline & Average & 21,05 & 33,56 \\
\hline \multirow{5}{*}{ 冚 } & 301 & 47,5 & 43,26 \\
\hline & 302 & 49,5 & 38,30 \\
\hline & 306 & 45,5 & 37,71 \\
\hline & 322 & 52 & 43,62 \\
\hline & Average & 48,63 & 40,72 \\
\hline \multirow{6}{*}{ 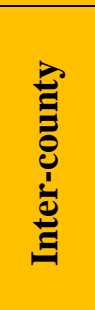 } & 307 & 40,5 & 26,96 \\
\hline & 308 & 35 & 29,31 \\
\hline & 310 & 34,5 & 30,96 \\
\hline & 311 & 57 & 41,79 \\
\hline & 313 & 40,5 & 37,04 \\
\hline & 315 & 31,5 & 33,14 \\
\hline
\end{tabular}




\begin{tabular}{|r|r|r|r|}
\hline & 325 & 17 & 50,47 \\
\cline { 2 - 4 } & 268 & 35 & 26,23 \\
\cline { 2 - 4 } & 330 & 30 & 30,60 \\
\cline { 2 - 4 } & Average & 35,67 & 33,66 \\
\hline \multicolumn{2}{|r|}{ AVERAGE } & 35,11 & 35,98 \\
\hline
\end{tabular}

Source: [3]

Table 1 shows the average speed of $36 \mathrm{~km} / \mathrm{h}$ in the city of Velika Gorica. The average speed is acceptable, but given that most of the routes don't operate in urban conditions, the average speed should be higher.

Table 2. Bus occupancy

\begin{tabular}{|c|c|c|c|c|c|}
\hline \multirow{2}{*}{\multicolumn{2}{|c|}{ Route }} & \multicolumn{4}{|c|}{ Bus occupancy, \% } \\
\hline & & Workday & \multirow{2}{*}{$\begin{array}{r}\text { Saturday } \\
11\end{array}$} & \multirow{2}{*}{$\frac{\text { Sunday }}{2}$} & \multirow{2}{*}{$\begin{array}{r}\text { Week } \\
13,5\end{array}$} \\
\hline \multirow{11}{*}{ శ్ } & 303 & 17 & & & \\
\hline & 304 & 16 & 8 & & 14,6 \\
\hline & 305 & 17 & 17 & 5 & 15,3 \\
\hline & 309 & 5 & 8 & 1 & 4,9 \\
\hline & 319 & 11 & 6 & 3 & 9,1 \\
\hline & 321 & 6 & 8 & 10 & 69 \\
\hline & 323 & 19 & 0 & 0 & 19,0 \\
\hline & 324 & 17 & 13 & 0 & 15 \\
\hline & \multirow{3}{*}{335} & 6 & 2 & 0 & 4,0 \\
\hline & & 11 & 0 & 0 & 11,0 \\
\hline & & \begin{tabular}{l|l} 
In total & 8,5
\end{tabular} & 1 & 0 & 7,5 \\
\hline \multicolumn{2}{|c|}{ TOTAL } & 12,50 & 7,30 & 2,10 & 11,33 \\
\hline \multirow{4}{*}{ 莽 } & 301 & 28 & 23 & 14 & 25,3 \\
\hline & 302 & 15 & 17 & 4 & 13,7 \\
\hline & 306 & 21 & 18 & 10 & 19,0 \\
\hline & 322 & 20 & 11 & 3 & 16,0 \\
\hline \multicolumn{2}{|c|}{ TOTAL } & 21,00 & 17,25 & 7,75 & 18,51 \\
\hline \multirow{9}{*}{ 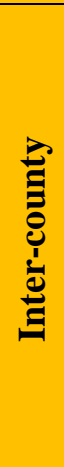 } & 307 & 26 & 15 & 9 & 21,4 \\
\hline & 308 & 23 & 13 & 7 & 19,2 \\
\hline & 310 & 18 & 12 & & 16,6 \\
\hline & 311 & 29 & 12 & & 25,4 \\
\hline & 313 & 10 & & & 10,0 \\
\hline & 315 & 19 & 18 & 8 & 16,7 \\
\hline & 325 & 22 & 13 & 0 & 17,5 \\
\hline & 268 & 50 & 33 & 23 & 42,9 \\
\hline & 330 & 43 & & & 43,0 \\
\hline \multicolumn{2}{|c|}{ TOTAL } & 26,67 & 16,57 & 9,40 & 23,47 \\
\hline
\end{tabular}

Source: [3]

As the data in Table 2 shows, bus occupancy is relatively small. Among local routes, the average usage is only $11.33 \%$, among county routes $18.51 \%$ and $23.47 \%$ among inter-county routes. The highest occupancy is on route 268 (Zagreb - Velika Gorica), with $50 \%$ on workdays and on route 330, with $43 \%$ on workdays. [3] 
Regarding the fact that the study of public transport was done 15 years ago, and the lack of significant changes in quality of service, it's obvious how transport changes are necessary for the City of Velika Gorica. [3]

Table 3 shows bus travel data for 2005 (when the last public transport study was made) and Table 4 shows the data for 2009, where it is evident how transport organization made only small changes - the operator cancelled routes 301 and 306, and route 302 operates only locally to Velika Buna. [3]

Table 3. Bus travel data, 2005

\begin{tabular}{|c|c|c|c|c|c|c|c|c|c|c|c|c|c|}
\hline \multirow{2}{*}{$\begin{array}{c}\text { Ordinal } \\
\text { number }\end{array}$} & \multicolumn{2}{|c|}{ Route } & \multirow{2}{*}{$\begin{array}{c}\text { Length, } \\
\text { km }\end{array}$} & \multirow{2}{*}{$\begin{array}{c}\text { Tariff } \\
\text { zone }\end{array}$} & \multicolumn{4}{|c|}{ Number of departures } & \multicolumn{5}{|c|}{ Distance traveled, km } \\
\hline & Type & Number & & & $\begin{array}{c}\text { work } \\
\text { day }\end{array}$ & saturday & sunday & weekly & $\begin{array}{c}\text { work } \\
\text { day }\end{array}$ & saturday & sunday & weekly & yearly \\
\hline 1 & \multirow{11}{*}{$\begin{array}{l}\text { 겅 } \\
\text { U્ } \\
0\end{array}$} & 303 & 15,9 & 3 & 18 & 14 & 6 & 55 & 286,2 & 222,6 & 95,4 & 1749 & 89644,20 \\
\hline 2 & & 304 & 17,9 & 1 & 10,5 & 5,5 & 0 & 58 & 187,95 & 98,45 & 0 & 1038,2 & 52742,35 \\
\hline 3 & & 305 & 11,9 & 1 & 32 & 22 & 6 & 188 & 380,8 & 261,8 & 71,4 & 2237,2 & 114216,20 \\
\hline 4 & & 309 & 11,4 & 2 & 20 & 12 & 6 & 118 & 228 & 136,8 & 68,4 & 1345,2 & 69038,40 \\
\hline 5 & & 319 & 9,3 & 1 & 3 & 4 & 10 & 29 & 27,9 & 37,2 & 93 & 269,7 & 14656,80 \\
\hline 6 & & 321 & 11,9 & 2 & 12 & 6 & 4 & 70 & 142,8 & 71,4 & 47,6 & 833 & 42863,80 \\
\hline 7 & & 323 & 16,4 & 1 & 9 & 0 & 0 & 45 & 147,6 & 0 & 0 & 738 & 37785,60 \\
\hline 8 & & 324 & 13,05 & 1 & 6 & 4 & 0 & 34 & 78,3 & 52,2 & 0 & 443,7 & 22498,20 \\
\hline 9 & & 325 & 14,3 & 2 & 23 & 15 & 0 & 130 & 328,9 & 214,5 & 0 & 1859 & 94279,90 \\
\hline \multirow[t]{2}{*}{10} & & 335 & $13,2(10)$ & 1 & 18 & 6 & 0 & 96 & 196 & 60 & 0 & 1040 & 52996,00 \\
\hline & & & In total & & 151,5 & 88,5 & 32 & 823 & 2004,5 & 1155 & 375,8 & 11553 & 590721,45 \\
\hline 11 & \multirow{5}{*}{ 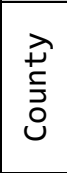 } & 301 & 14,3 & 4 & 25 & 15 & 14 & 154 & 357,5 & 214,5 & 200,2 & 2202,2 & 11401,90 \\
\hline 12 & & 302 & 14,1 & 4 & 17 & 13 & 4 & 102 & 239,7 & 183,3 & 56,4 & 1438,2 & 73475,10 \\
\hline 13 & & 306 & 9,05 & 4 & 26 & 15 & 6 & 151 & 235,3 & 135,75 & 54,3 & 1366,6 & 69983,65 \\
\hline \multirow[t]{2}{*}{14} & & 322 & 22,5 & 5 & 6 & 5 & 6 & 41 & 135 & 112,5 & 135 & 922,5 & 48217,50 \\
\hline & & & In total & & 74 & 48 & 30 & 448 & 967,5 & 646,05 & 445,9 & 5929,5 & 305690,15 \\
\hline 15 & \multirow{9}{*}{ 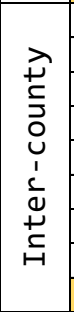 } & 307 & 14,8 & 3 & 17 & 13 & 6 & 104 & 251,6 & 192,4 & 88,8 & 1539,2 & 78958,00 \\
\hline 16 & & 308 & 13,7 & 3 & 41 & 23 & 6 & 234 & 561,7 & 315,1 & 82,2 & 3205,8 & 163701,30 \\
\hline 17 & & 310 & 14,8 & 2 & 30 & 10 & 0 & 160 & 444 & 148 & 0 & 2368 & 120620,00 \\
\hline 18 & & 311 & 20,65 & 5 & 14 & 10 & 0 & 80 & 289,1 & 206,5 & 0 & 1652 & 83715,10 \\
\hline 19 & & 313 & 14,6 & 3 & 4 & 0 & 0 & 20 & 58,4 & 0 & 0 & 292 & 14950,40 \\
\hline 20 & & 315 & 3,7 & 2 & 28 & 16 & 10 & 166 & 103,6 & 59,2 & 37 & 614,2 & 31598,00 \\
\hline 21 & & 268 & 5,6 & 2 & 269 & 215 & 159 & 1719 & 1506,4 & 1204 & 890,4 & 9626,4 & 497431,20 \\
\hline \multirow[t]{2}{*}{22} & & 330 & 5,6 & 2 & 104 & & & 520 & 582,4 & 0 & 0 & 2912 & 149094,40 \\
\hline & & \multicolumn{3}{|c|}{ In total } & 507 & 287 & 181 & 3003 & 3797,2 & 2125,2 & 1098,4 & 22210 & 1140068,40 \\
\hline \multicolumn{5}{|c|}{ In total } & 732,5 & 423,5 & 243 & 4274 & 6769,2 & 3926,2 & 1920,1 & 39692 & 2036480 \\
\hline
\end{tabular}

Source: [3]

Table 4. Bus travel data, 2009 
Vidan, L., Slavulj, M., Šojat, D. / Public Transport \& Smart Mobility 2020, 39-49

\begin{tabular}{|c|c|c|c|c|c|c|c|c|c|c|c|c|c|}
\hline \multirow{2}{*}{$\begin{array}{c}\text { Ordinal } \\
\text { number }\end{array}$} & \multicolumn{2}{|c|}{ Route } & \multirow{2}{*}{$\begin{array}{l}\text { Length, } \\
\mathrm{km}\end{array}$} & \multirow{2}{*}{$\begin{array}{c}\text { Tariff } \\
\text { zone }\end{array}$} & \multicolumn{4}{|c|}{ Number of departures } & \multicolumn{5}{|c|}{ Distance traveled, km } \\
\hline & Type & Number & & & $\begin{array}{c}\text { work } \\
\text { day }\end{array}$ & saturday & sunday & weekly & $\begin{array}{c}\text { work } \\
\text { day }\end{array}$ & saturday & sunday & weekly & yearly \\
\hline 1 & \multirow{11}{*}{$\begin{array}{l}\text { 겅 } \\
\text { Uે }\end{array}$} & 302 & 10 & 3 & 32 & 16 & 10 & 102 & 320 & 160 & 100 & 1860 & 95640 \\
\hline 2 & & 303 & 15,9 & 3 & 22 & 14 & 6 & 55 & 349,8 & 222,6 & 95,4 & 2067 & 105925,80 \\
\hline 3 & & 304 & 17,9 & 1 & 11 & 5,5 & $\theta$ & 60,5 & 196,9 & 98,45 & 0 & 1083 & 55033,55 \\
\hline 4 & & 305 & 11,9 & 1 & 32 & 24 & 6 & 190 & 380,8 & 285,6 & 71,4 & 2261 & 115334,80 \\
\hline 5 & & 309 & 11,4 & 2 & 20 & 12 & 6 & 118 & 228 & 136,8 & 68,4 & 1345,2 & 69038,40 \\
\hline 6 & & 319 & 9,3 & 1 & 4 & 4 & 10 & 34 & 37,2 & 37,2 & 93 & 316,2 & 17037,60 \\
\hline 7 & & 321 & 11,9 & 2 & 12 & 6 & 5 & 71 & 142,8 & 71,4 & 59,5 & 844,9 & 43601,60 \\
\hline 8 & & 323 & 16,4 & 1 & 9 & 0 & $\theta$ & 45 & 147,6 & $\theta$ & 0 & 738 & 37785,60 \\
\hline 9 & & 324 & 13,05 & 1 & 32 & 15 & 8 & 183 & 417,6 & 195,75 & 104,4 & 2388,2 & 122578,65 \\
\hline \multirow[t]{2}{*}{10} & & 335 & $\mid 13,2(10)$ & 1 & 18 & 7 & 0 & 96 & 196 & 60 & 0 & 1040 & 52996,00 \\
\hline & & \multicolumn{3}{|c|}{ In total } & 160 & 87,5 & 41 & 852,5 & 2096,7 & 1107,8 & 492,1 & 12083 & 714972,00 \\
\hline 12 & \multirow{2}{*}{ County } & 325 & $14,3 \mid$ & 2 & 25 & 15 & 0 & 140 & 357,5 & 214,5 & 0 & 2002 & 101601,50 \\
\hline 13 & & \multicolumn{3}{|c|}{ In total } & 25 & 15 & $\theta$ & 140 & 357,5 & 214,5 & 0 & 2002 & 101601,50 \\
\hline 14 & \multirow{10}{*}{ 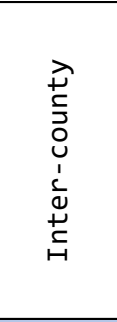 } & 307 & \begin{tabular}{|r|}
14,8 \\
\end{tabular} & 3 & 17 & 13 & 5 & 104 & 251,6 & 192,4 & 74 & 1524,4 & 78040,40 \\
\hline 15 & & 308 & 13,7 & 3 & 38 & 23 & 6 & 234 & 520,6 & 315,1 & 82,2 & 3000,3 & 153179,70 \\
\hline 16 & & 310 & 14,8 & 2 & 50 & 17 & 0 & 160 & 740 & 251,6 & 0 & 3951,6 & 201265,20 \\
\hline 17 & & 311 & 20,65 & 5 & 14 & 10 & $\theta$ & 80 & 289,1 & 206,5 & 0 & 1652 & 83715,10 \\
\hline 18 & & 313 & 14,6 & 3 & 5 & 3 & 0 & 20 & 73 & 43,8 & 0 & 408,8 & 20746,60 \\
\hline 19 & & 315 & 3,7 & 2 & 31 & 18 & 10 & 166 & 114,7 & 66,6 & 37 & 677,1 & 34787,40 \\
\hline 20 & & 268 & 5,6 & 2 & 275 & 225 & 167 & 1719 & 1540 & 1260 & 935,2 & 9895,2 & 511442,40 \\
\hline 21 & & 330 & 5,6 & 2 & 103 & & & 520 & 576,8 & 0 & 0 & 2884 & 147660,80 \\
\hline \multirow[t]{2}{*}{22} & & 322 & 22,5 & 5 & 6 & 5 & 6 & 41 & 135 & 112,5 & 135 & 922,5 & 48217,50 \\
\hline & & \multicolumn{3}{|c|}{ In total } & 539 & 314 & 194 & 3044 & 4240,8 & 2448,5 & 1263,4 & 24916 & 1279055,1 \\
\hline \multicolumn{5}{|c|}{ In total } & 724 & 416,5 & 235 & 4036,5 & 6695 & 3770,8 & 1755,5 & 39001 & 2095628,6 \\
\hline
\end{tabular}

Source: [3]

From the data in Table 3 and Table 4, it's obvious how, no matter the two cancelled routes (301 and 306) and shortened route 302 , in 2009, travelled distance became larger.

\section{Discussion}

After analysing public passenger transport in Velika Gorica and its surrounding settlements, it's evident that there are some improvements needed. In the study of public transport from 2005, the analysis showed many public transport routes poorly utilizing available passenger seats (Table 2), which indicates a need to consolidate the process.

In terms of low vehicle occupancy, there's insufficient transport demand, which can be solved by introducing lowcapacity buses, or by reducing the number of departures. Many routes don't justify their existence economically because of low vehicle occupancy (Table 2), but they are important for the residents depending on these routes, despite the lack of space for improvement. These routes should start using minibuses to increase vehicle occupancy and reduce the costs, improving their economic justification. Departure frequency is also important because of transport demand. As explained in Chapter 4, transport demand is the highest in the morning, when many adults and children go to work or school, and yet some of the routes don't departure in the morning.

By analysing routes 268 and 330, the average speed difference is relatively small despite that the Route 330 (Zagreb - Velika Gorica) is an express route. Therefore, Route 330 should be terminated, and Route 268 should increase departure frequency. Consequently, the passengers would be more satisfied, as the survey reported many of the passengers unhappy with the regularity and comfort of the service.

To implement any of the given alternatives in practice, a detailed analysis of public transport demand, with investigating possibilities to reconstruct public transport network, should be conducted.

\section{Conclusion}

Demand for local public transport is growing every year. More people are starting to use buses, trains, trams, and other modes of public transport rather than private car. The cost of owning a private vehicle is pushing people towards public transport because of the costs, such as registration, gas, yearly maintenance and so on. Public 
transport is not only cost-effective, but it's also better for environment and for future city growth. But for the people to use public transport, it needs to be punctual, comfortable, fast, secure and cheap.

Local public transport in City of Velika Gorica is fairly spread given it contains 58 settlements. As a lot of those settlements have a population smaller than 1000 residents, many of those routes aren't economically effective but if these routes didn't exist, the conditions for residents wouldn't be acceptable.

Based on conducted survey, the majority of passengers are unhappy with current public transport service, and the greatest dissatisfactions are related to frequent bus delays, departure regularity and schedule adherence. With the new timetables proposed for these three routes, based on the survey, the problem with regularity would be solved, but the travel time problem wouldn't, because in commuter periods, buses share the infrastructure with private cars.

\section{References}

[1] Kušević D. Prijedlog poboljšanja prijevoza putnika na relaciji Velika Gorica - Zagreb (master's thesis). Faculty of Transport and Traffic Sciences. Zagreb. 2017.

[2] Census of Population, Households and Dwellings 2011. Zagreb: Croatian Bureau of Statistics.

[3] Gradski ured za strategijsko planiranje i razvoj grada. Available at: https://www.zagreb.hr/gradski-uredza-strategijsko-planiranje-i-razvoj-g/821 [Accessed: November 10,2020]

[4] Prometis d.o.o. Prometna studija Grada Velika Gorica. Prometis d.o.o. Zagreb. 2010.

[5] Upravni odjel za komunalne djelatnosti i promet. Grad Velika Gorica. Available at: http://www.gorica.hr/upravni-odjel-za-izgradnju-komunalne-djelatnosti-i-promet/ [Accessed: November $13,2020]$ 